\title{
Obituary.
}

Sir George KNIbis, C.M.G.

$\mathrm{B}^{\mathrm{r}}$ $Y$ the death of Sir George Handley Knibbs at Melbourne, on Mar. 30, science in Australia has lost one of her most forceful and enthusiastic workers.

Sir George was born in Sydney in June 1858. As a surveyor and civil engineer he took an active part in the topographical survey of New South Wales. He then became acting professor of physics at the University of Sydney. In 1906 he was appointed Commonwealth Statistician, and in that capacity brought out the Commonwealth Year Book, which, by reason of its comprehensive and accurate nature, is one of the best statistical publications in the world.

After serving for fifteen years as Commonwealth Statistician, Sir George Knibbs was appointed in 1921 Director of the Commonwealth Institute of Science and Industry, which post he held until his retirement from public life in 1926. The Institute was then reconstructed as the Council for Scientific and Industrial Research. While under his direction, the small staff of the Institute commenced a number of important lines of investigation, some of which have recently passed from success in the laboratory to the sphere of commercial scale tests. These included research into the manufacture of paper pulp from Australian hardwoods, power alcohol production, the eradication of prickly pear, and the utilisation of Australian pottery clays. Knibbs deplored the inevitable whittling away of funds intended for research purposes, due to political indifference, which lessened the value of the Institute to the nation. The constitution of the Institute, however, did not favour its fullest cooperation with the universities and other State bodies; nor did the somewhat autocratic manner of the director attract his Australian fellow scientific workers. Both features were undesirable in a national research body.

Throughout his public life Sir George Knibbs took an active part in social legislation and served on Royal Commissions concerned with education, social and other forms of insurance, taxation of crown leaseholds, trade, and industry. As Commonwealth Statistician, he devised the mathematical formulæ on which the Commonwealth land and income taxes are assessed.

Though his activities were more of an administrative nature, Sir George contributed to the scientific press numerous monographs on pure mathematics, geodesy, and geodetic instruments. His larger contributions include "The Mathematical Theory of Population," "The Census of Wealth," and a recent book, "The Shadow of the World's Future "-a study of the relation of world population growth to food production and migration influences. From a statistical basis, he emphasises the need for modification in national policies to avert the danger of over-population.

Sir George Knibbs was a fellow of the Royal Astronomical Society, an honorary fellow of the
Statistical Society, and a member of the International Institute of Statisticians. He attended many international congresses, where his sound knowledge of foreign languages, backed by a comprehensive grasp of scientific affairs, made him an able and worthy representative of the Commonwealth. Although in recent years his health was failing, this disability seems to have had little effect on the keenness and brilliance which he applied to the welfare of Australian scientific organisations. The knighthood bestowed on him in 1923 was regarded in Australia as a fitting recognition of the devoted and brilliant service he had rendered to his country.

\section{Sir Henry Rew, K.C.B}

THE death at his house at Wormshill, Kent, on April 7, at the age of seventy years, of Sir Henry Rew removes a leading authority on agricultural economics and, in the old sense of the word, statistics. For some years prior to 1906 he was in charge of the Statistical Branch of the Ministry of Agriculture and Fisheries, and after his promotion in that year to the post of assistant secretary, his predominant interest lay in the annual reports on agricultural statistics, for which he was personally responsible. To his work in this field is largely due the fullness and comparability of the series of returns on British agriculture. His initiative may be exemplified by the estimates made by a committee of the Royal Statistical Society, from returns from representative dairies and slaughterhouses of the production of milk and meat in the British Isles.

The two addresses given by Sir Henry Rew as president of the Royal Statistical Society were devoted to "The Organisation of Statistics " and to "The Progress of British Agriculture." In the first of these he emphasised that " The real question . . is not the present defects of the official statistics or the delinquencies of official statisticians, but the deficiencies of the present system and the inadequacy of the available resources." After quoting the several high authorities who at different times had urged the importance of the establishment of a centralised statistical department, he expressed his own conviction of the need for "a general overhaul of official statistical machinery, and for some drastic measure for securing co-ordination." The function of the Royal Statistical Society should be to assist in forming an appreciative, watchful, and well-informed public opinion.

Sir Henry's second address to the Royal Statistical Society was largely a historical account of agricultural statistics leading to the important conclusion that while the statistical data were unable to prove the case, an examination of the statistics so far as they were available pointed to the conclusion that a larger quantity of food was being produced at the outbreak of War than at any previous period, and this in spite of a shrinking acreage. 